Pakistan Journal of Humanities \& Social Science Research

Volume No. 02, Issue No. 01(June, 2019)

\title{
TRAINING AND DEVELOPMENT IMPACT ON EMPLOYEES PERFORMANCE: A STUDY OF GOVERNMENT COLLEGES OF HYDERABAD-PAKISTAN
}

\author{
Syed Nadeem Juman Shah*, Riaz Hussain Shah, \& Prof.Dr. Muneeruddin \\ Soomro
}

\begin{abstract}
This study explored the "Training and development impact on employee's performance: a case study of government colleges". The main aim of the study was to find out the government colleges training and development programs in Hyderabad, Pakistan.110 samples were used through primary data collection from seniorstaff of colleges. Self administered questionnaires were used and all collected data were analyzed through SPSS $23 v$ software with help of demographical and descriptive information. This research is relevant to organizational issues, which shows lack of management's supports to trainings and developments programs. Results provide significant and positive impact on employee's performance through trainings and developments in the government colleges of Hyderabad, Pakistan. This research recommends the colleges of government's orders into doing well. Government's college of Hyderabad-Pakistan, all Organizational Headd departments were engaged there in training and development. These trainings and development built employee's strengthen and potential of employee's competency.
\end{abstract}

Key Words: Training, Development, Employees Performance, Hyderabad-Pakistan 


\section{INTRODUCTION:}

The offer to defeat these difficulties, there has for the most part been the requirement for an extensive human asset the executives (HRM) practices to change over association's HR into a reasonable upper hand. Along these lines, one method for inciting these associations is to prepare their workers legitimately to upgrade their execution (Cohen, 2017). Since workers are considered as a circulation system, most profitable resources, and crucial wellspring of upper hand in the associations (Larsen, H. H., 2017). In this manner, getting ready is fundamental with the true objective to get qualified workforce who are really and socially capable and prepared for livelihood headway into master or the official's positions (Stephens et al., 2017).In any association, the necessities of preparing rise are there so as to enhance both representative and authoritative execution (Fletcher, Alfes, \& Robinson, 2018). Government schools are open area tertiary instructive organizations which were set up by a demonstration of parliament, Act 745 , 2007. It is anyway a semi-self-ruling establishment and along these lines the enrollment, determination, preparing and advancement of its workers are obligation of the administration. Government schools which began as tertiary foundation in 1993 at present has more than four hundred representatives made up of the board, scholarly staff (Lecturer to Professor) and authoritative staff (office representatives, workshop collaborators and experts, drivers, security and cleaners and so forth). According to (Frost, 2016). The regulatory staffs (office representatives) are additionally organized into the executives on their ranking staff and junior staff. This examination led among the board individuals are the administrators of both ranking staff and junior staff.

\section{Training \& Developments}

"Training is the formal and systematic modification of behavior through learning which occurs as a result of education, instruction, development and planned experiences."

"Development is any learning activity, which is directed towards future, needs rather than present needs and which is concerned more with career growth than immediate performance."

\section{Types of Trainings \& Developments}

There are two type of training \& developments programs for employes in any organization 
$1^{\text {st }}$ is On Job Training and $2^{\text {nd }}$ is Off Job Training and Development Programs further classified theses type of training and development in following

On job Training Program:

Job duties, Job rotation, Staff development meetings, Problem solving seminars, Monitoring Special assignments and assessment, Aprenticeships

Off Job Training Programs:

Outside short courses and seminar, Colleges or universities certificates degrees Programs, Update managements program, communication college, outer surface meeting \& conference.

\section{LITERATURE REVIEW:}

According to (Aboyassin \& Sultan, 2017) explain that the offer to defeat these difficulties, there has for the most part been the requirement for an extensive human asset the executives (HRM) practices to change over association's HR into a reasonable upper hand. Along these lines, one method for inciting these associations is to prepare their workers legitimately to upgrade their execution.

In this manner, getting ready is fundamental with the true objective to get qualified workforce who are really and socially capable and prepared for livelihood headway into master or the official's positions (Mullins, 2010; Antwi et al., 2016).In any association, the necessities of preparing rise is there so as to enhance both representative and authoritative execution (Getahun, 2018).

Government College's Training an Development is part of HRD and every education sector need to provide best training and development programs to their college academic and ministrial staff. Why employees needs training?. To acquiring knowledge for working condition in Governemnt colleges through implemented new technology change. To be benefited by Promotion and provided new assignement or subject, increase salary may provide more responsibilities (Amin, 2013).

\section{Purposes of Training and Development}

Satisfaction of person's growing needs, Improvement of college performance, Reduce managerial obsolescence, Improve quality of education and productivity and also researchers point out theses variable for future research work condition, teachers 
performance in college, clerical staff efficiency, employees needs and compensations (Powell, and McGrath, 2019).

\section{RESEARCH GAP:}

After literature reviews data, I come to know that there are most trainings and development programs arranged by multinational companies and banking sector organizations. Recently private colleges arranged training and development programs for their employees, and International and other province employees of government colleges benefited through training ad development programs, but government colleges in Hyderabad still need training and development programs. It was a research gap for me to conduct study in government colleges in HyderabadPakistan

\section{RESEARCH OBJECTIVES}

1. To examine the efficiency of government colleges employees after getting training and development and fulfill government colleges

2. To Explore government colleges employees issues constantly after getting training and development

3. To determine government college employees requirements for training and development

4. To examine training and development effect on government college teachers performance

5. To determine the training and development effect on college's clerical staff

\section{RESEARCH HYPOTHESIS:}

H1: Government Colleges Training Programs has a significant relationship with employees efficiency

$\mathrm{H} 2$ : $\quad$ Significant and positive relationship between Training and employees needs

H3: Significantly \& Positively relation with training and Teachers performance

H4: significantly and Positively relation with training and clerical staff performance

H5: Training \& development association with working condition

\section{RESEARCH METHODOLOGY:}

There are so many research methods used in training and development study, for data collection outcomes of training such as Questionnaires, Tests, Interviews, human resource factors, cost 
benefit analysis, feedback. My research study is based on mixed methodology and has used both qualitative and quantitative processes of data collection.

Secondary data were collected through previously published articles, records, case studies, periodical reports, books and internet surfing and secondary data analyzed through content Analysis Techniques.

Primary data were collected through 110 closed ended questionnaires from employees of Government College in Hyderabad, Pakistan and they are analyzed in soups $22 \mathrm{v}$.

Population Targeted for research

All Government Colleges of Hyderabad, Pakistan were targeted, such colleges name and their sample distribution asunder.

Table 1: Government Colleges in Hyderabad, Pakistan

\begin{tabular}{|c|c|c|}
\hline Sr. No & Colleges Name & $\begin{array}{ll}\text { Sample } & \text { Size } \\
\text { Distribution }\end{array}$ \\
\hline \multirow[t]{2}{*}{1} & $\begin{array}{lll}\text { Government } & \text { Sachal } & \text { sarmast }\end{array}$ & 25 \\
\hline & Commerce College Hyderabad & \\
\hline 2 & $\begin{array}{l}\text { Government Kali Mori College } \\
\text { Hyderabad }\end{array}$ & 25 \\
\hline 3 & $\begin{array}{l}\text { Government Degree } \\
\text { Oasimabad Hyderabad }\end{array}$ & 25 \\
\hline 4 & $\begin{array}{l}\text { Government Jannah } \\
\text { College,Hyderabad }\end{array}$ & 10 \\
\hline \multirow[t]{2}{*}{5} & $\begin{array}{l}\text { Government Zubaida Girls College } \\
\text { Hyderabad }\end{array}$ & 25 \\
\hline & Total & 110 \\
\hline
\end{tabular}

RESULTS AND FINDINGS

Table 2: Cronbach's Alpha score of all Constructs

Reliability Report

\begin{tabular}{ll}
\hline Cronbach's Alpha & No. of Items \\
\hline .892 & 110 \\
\hline
\end{tabular}

Demographical Information:

Table 3: Demographic Statistics of Study

\begin{tabular}{llll}
\hline Items & Categories & Frequency & Percent \\
\hline Gender & Male & 75 & $68 \%$ \\
\hline
\end{tabular}




\begin{tabular}{llll}
\hline \multirow{4}{*}{ Education } & Female & 35 & $32 \%$ \\
& Total & $\mathbf{1 1 0}$ & $\mathbf{1 0 0 \%}$ \\
& Graduate & 86 & $78 \%$ \\
& M.Phil \& above & 24 & $22 \%$ \\
& Total & $\mathbf{1 1 0}$ & $\mathbf{1 0 0 \%}$ \\
Age & $18-28$ & 52 & $47 \%$ \\
& $29-43$ & 28 & $26 \%$ \\
& Above 43 & 30 & $27 \%$ \\
& Total & $\mathbf{1 1 0}$ & $\mathbf{1 0 0 \%}$ \\
Designation & College Teacher & 76 & $69 \%$ \\
& Clerical staff & 34 & $31 \%$ \\
& Total & $\mathbf{1 1 0}$ & $\mathbf{1 0 0 \%}$ \\
\hline
\end{tabular}

Table 2 shows the result of respect to respondent gender, education, age, and designation that $68 \%$ of the Government College employees were male and $32 \%$ of the College employees were female and results about college employees education, $86 \%$ of the Government College employees were education till than gradation, $24 \%$ of the Government College employees were educated till M.Phil and Above degree, while results regarding Government College employees age level, 52\% percent of the College employees were 18-28 years of age group and 28\% of Government College employees were belong to 29-43 years of age group and 30\% of the Government Colleges employees were belong to above 43 years of age group on the other hand the results about designation of College employees were $76 \%$ of the Government College employees were working as a Teaching post while $34 \%$ of the Government college employees were working as a Clerical Staff.

\section{Descriptive Statistics Information:}

Table 4: Descriptive Statistics of the veriables

\begin{tabular}{llll}
\hline Variables & N & Mean & Std. Deviation \\
\hline Working Condition & 110 & 4.231 & .59356 \\
Trainings & 110 & 3.251 & .82671 \\
Relationship Teacher & 110 & 4.568 & .62783 \\
Relationship Clerical Staff & 110 & 3.523 & .52145 \\
Needs and Compensations & 110 & 3.861 & .57254 \\
\hline
\end{tabular}




\section{Valid N (Listwise) 110}

\section{HYPOTHESES TESTING:}

Table 5: Hypotheses Testing \& Statement Summary

\begin{tabular}{|c|c|c|}
\hline Hypotheses & Items categories & $\begin{array}{l}\text { Supported or Not } \\
\text { Supported }\end{array}$ \\
\hline H1: & $\begin{array}{l}\text { Government Colleges Training } \\
\text { Programs } \quad \text { significantly } \\
\text { relationship with employees } \\
\text { efficiency }\end{array}$ & Accepted \\
\hline H2: & $\begin{array}{l}\text { Significant and positive } \\
\text { relationship between Training } \\
\text { employees needs }\end{array}$ & Not Accepted \\
\hline H3: & $\begin{array}{l}\text { Significantly \& Positively } \\
\text { related with training and } \\
\text { Teachers performance }\end{array}$ & Accepted \\
\hline H4: & $\begin{array}{l}\text { significantly and Positively } \\
\text { related with training and } \\
\text { clerical staff performance }\end{array}$ & Accepted \\
\hline H5. & $\begin{array}{l}\text { Training \& development } \\
\text { associated with } \quad \text { working } \\
\text { condition }\end{array}$ & Accepted \\
\hline
\end{tabular}

\section{CONCLUSION}

On base's results, we are capable to see that selected training and development programs such as working condition of government college employees, relationship with teachers and relationship with clerical staff are important factors which have significant and positive impact on training and development performance of government college Hyderabad. 
This research study also concluded that "compensation" is the factor which is influencing most training and development level of government college Hyderabad

\section{RECOMMANDATION:}

This research is conducted only in Hyderabad city, I recommend further researchers to examine the performance of government as well as private colleges in other province and cities of Pakistan.

\section{REFERENCES}

1. Amin, A., Saeed, R., Lodhi, R. N., Mizna, S., Iqbal, A., \& Tehreem, R. (2013). The impact of employees training on the job performance in education sector of Pakistan. Middle-East Journal of Scientific Research, 17(9), 1273-1278.

2. Cohen, E. (2017). Employee training and development. In CSR for HR (pp. 153-162). Routledge.

3. Fletcher, L., Alfes, K., \& Robinson, D. (2018). The relationship between perceived training and development and employee retention: the mediating role of work

4. Frost, S. (2016). The importance of training \& development in the workplace. Small Business, http://smallbusiness. chron. com/importance-trainingdevelopment-workplace-10321. Html

5. Larsen, H. H. (2017). Key issues in training and development. In Policy and practice in European human resource management (pp. 107-121). Routledge.

6. Powell, L. and McGrath, S., 2019. Capability or Employability: Orientating VET Toward "Real Work". Handbook of Vocational Education and Training: Developments in the Changing World of Work, pp.1-25.

7. Stephens, T., De Silva, A. P., Beane, A., Welch, J., Sigera, C., De Alwis, S., ... \& Abeynayaka, A. (2017). Capacity building for critical care training delivery: development and evaluation of the Network for Improving Critical care Skills Training (NICST) programme in Sri Lanka. Intensive and Critical Care Nursing, 39, 28-36. 